\section{Концентрация тяжелых металлов в снежном покрове и реакция лесных насаждений на эмиссии}

\author{
И. А. Царев ${ }^{1}$ \\ Воронежская государственная лесотехническая \\ академия
}

В работе исследуется количественное содержание железа, марганца, меди, кадмия, цинка и свинца (продуктов отработавших газов автомобильного транспорта) в снежном покрове придорожной полосы и лесного массива, прилегающего к автостраде МоскваВоронеж, и показана реакция сосновых насаждений на эмиссии.

Ключевые слова: газы автотранспорта, дигрессия, загрязнение окружающей среды, лесные массивы, техногенез, тяжелые металлы, эмиссии.

В настоящее время города, близлежащие сельхозугодья и лесные массивы все больше подвергаются антропогенному воздействию, что пагубно сказывается на их состоянии, а в отдельньх случаях возникает критическая экологическая обстановка.

В комплексе антропогенных факторов, отрицательно действующих на природную среду, особое место по масштабам и опасности воздействия составляют промышленные и автотранспортные выбросы. Причем во многих регионах автотранспорт занимает ведущее место среди всех видов источников загрязнения окружающей среды, и его доля ежегодно увеличивается. Уже сейчас, по данным ряда авторов, автомобили вносят от 44 до $90 \%$ от суммарного выброса загрязняющих веществ в атмосферу [1-4].

В атмосферу попадает целый спектр тяжельх металлов, пыли и нефтепродуктов, которые по токсичности и влиянию на окружающую среду в большинстве случае имеют наибольший вес. Наибольшее влияние на окружающую среду и человека, по данным Ю. В. Ивановой, А. Т. Козлова и др., оказывают свинец, цинк, кадмий, медь, марганец, железо и др. [5-6].

Мерилом токсичности техногенной нагрузки, по данным Ю. В. Ивановой, считается заболеваемость детей, которая в районах с интенсивным автомобильным движением в 3-5 раз выше, чем в экологически безопасных. Врожденные аномалии и пороки у детей различньх регионов за последние десятилетие увеличились более чем в три раза и достигают 31 - 44\% [4, 5].

Воздействие отработавших газов автотранспорта и других эмиссий гораздо раньше можно проследить на

\footnotetext{
${ }^{1}$ Автор - аспирант лесоинженерного факультета ВГЛТА

(C) И. А. Царев, 1999
}

лесньгх насаждениях, так как восприимчивость древесньх видов к загрязнению многими фитотоксикантами значительно выше, чем у человека или животных [7]. В придорожньг насаждениях растения теряют устойчивость и способность к самовозобновлению, у них снижается интенсивность роста, сокращается продолжительность жизненного цикла, наблюдаются изреживание и гибель насаждений $[8,9]$.

На смену лесам на обширных территориях приходит степная растительность, а иногда и пустыня [6]. За последние годы в ряде западноевропейских стран в результате загрязнения атмосферы эмиссиями резко возросли масштабы повреждений и отмирания лесов. Так, по данным Lehringer, Wunder, Brelon, Kirch и др., такие повреждения лесов в ФРГ составляли $34 \%$. Из хвойньх пород наиболее сильно повреждались пихта $(87 \%)$, сосна $(59 \%)$ и ель $(51 \%)$; из лиственньх - бук $(50 \%)$ и дуб $(43 \%)[10,11]$.

По данным П. С. Пастернака и др., площадь поврежденных лесов в ФРГ составляла около 2,5 млн. га, в Польше - 654 тыс. га, в Чехословакии - 692 тыс. га, в Австрии - 200 тыс. га. В долине р. Коптер в восточной части США (штат Теннесси) от выброса сернистого ангидрида и тяжелых металлов полностью повреждены и превратились в "промышленную пустыню" 2800 га смешанньх лесов, а на площади 6900 га осталась только травянистая растительность [7]. Охрана лесов от повреждения эмиссиями считается серьезной проблемой и в Великобритании, Швеции, Швейцарии и других стран [10].

Для выявления причин аномалий роста и сохранности лесных насаждений, связанных с загрязнением среды, необходимы количественные оценки пространственных и временных изменений, выявление связи наблюдаемых изменений с потеншиальными причинами этих явлений, изучение химических и физикомеханических свойств древесины, анализ почв на наличие токсичных тяжельх металлов.

Наиболее полно изучено воздействие на древесную растительность двуокиси серы и окиси азота [7, 12, 13]. По данным исследований Х. Г. Десслера и др., весьма восприимчивы к загрязнению $\mathrm{SO}_{2}$ ель, сосна, лиственница; маловосприимчивы - дуб, клен, ива, береза [12]. По данным S. Huttunen (цит. по П. С. Пастернаку и др. [7]), для хвойньх пород опасна среднегодовая концентрация токсикантов $\mathrm{SO}_{2}=$ $0,03 \mathrm{Mr} / \mathrm{M}^{3}$, для березы - $0,05 \mathrm{Mr} / \mathrm{m}^{3}$. К окиси азота наиболее восприимчивы береза и лиственница; средняя степень восприимчивости характерна для клена, липы, ели; наиболее устойчивыми считаются дуб и ильм. Р. Гудериан порогом токсичности окиси азота при долговременном воздействии на лес считает $350 \mathrm{MKr} / \mathrm{M}^{3}$ [13].

Древесные породы очень удобны для биомониторинга, некоторые из них сильно реагируют на промышленные и автотранспортные эмиссии и могут выступать в качестве биоиндикаторов. 
По данньм А. И. Федоровой и др. $[1,15]$, наиболее чувствительными к выхлопным газам автомобильного транспорта среди лиственных пород оказались каштан конский, липа, клен, осина и белые тополя.

А. М. Луговской подчеркивает, что лесные насаждения реагируют на загрязнение атмосферного воздуха при более низкой конщентрации, чем человек, и поэтому уровень ПДК (например для сосны) необходимо уменьшить до 0,2 от ныне существующего [14].

Влияние тяжельх металлов отработавших газов автомобильного транспорта на лесные сообщества изучено недостаточно. Оценку загрязнения этими эмиссиями конкретного района, как считают Н. М. Дронин, В. А. Агафонов, Г. П. Бутанов, А. Г. Ильдерханов и др. $[3,16]$, можно проводить по загрязнению снежного покрова. Снежный покров отражает всю геохимическую ситуацию за зимний период благодаря высокой сорбционной способности. Во время снегопада снежный покров получает из атмосферы существенную часть продуктов техногенеза. В нем аккумулируются также все выпадающие из воздуха вещества в периоды между снегопадами.

С целью получения детальной картины загрязнения воздушной и придорожной среды отработавшими газами автомобилей на автотрассе Москва - Воронеж вблизи г. Воронежа в районе Правобережного лесничества (кварталы № 40, 42, 44, 46, 48, 50) в 1995 1996 годах проводилось определение тяжелых металлов в снежном покрове. Отбор снежньх проб массой до 2 кг осуществлялся на протяжении от 579 до 582 км и на расстоянии от оси шоссе 5, 19, 24 и 29 м в 20 точках.

В пробах определялось содержание свинца и цинка (1 класс опасности), меди и кадмия ( 2 класс), марганца и железа (3 класс опасности). Данные получены при помощи экспрессного анализа проб (без предварительной их подготовки) рентгеновским анализатором АР-104. Результаты определений представлены в табл.1. Сравнение результатов проводилось с контрольньми пробами, взятыми во время снегопада в районе Усманского бора как наиболее отдаленного от промышленных районов Воронежа.

Исследования показали, что максимальная концентрация тяжельх металлов в снежном покрове придорожного пространства наблюдалась в 24-метровой зоне и превышала контроль в следующих пределах: меди - в 1,2-3,8; цинка - в 1,1-1,9; марганца - в 1,4-12; железа - в 1,7-10,4; кадмия - в 1,3-3,3 и свинца - в 2-9 раз. Пиковые значения конщентрации тяжельх металлов в этой зоне приходятся на территорию, прилегающую к посту Государственной автоинспекции (ГАИ), расположенному у 580-го километра трассы, и превышают ПДК в десятки раз.

В лесном массиве (29 м от оси шоссе) концентрация тяжельх металлов в снежном покрове резко снижалась (по цинку и свинцу - в $1,5-2$, меди и марганцу - в
4-4,5, по железу - в 5 раз) и по большинству показателей приближалась к контролю. Исключение составляли свинец, содержание которого превышало контроль в 2,5-3 раза, и кадмий, рассеяние которого было почти равномерным.

Для выяснения санитарного состояния древостоя Правобережного лесничества в местах примыкания $\mathbf{k}$ автостраде Москва - Воронеж были обследованы культуры сосны, испытывающие различную степень рекреационной нагрузки. Полученный материал свидетельствует о том, что в непосредственной близости к автостраде встречается наибольшее количество поврежденных, усьхающих и уже усохших деревьев (табл. 2).

Статистическая обработка полученных данных подтвердила зависимость состояния лесньх насаждений от интенсивности антропогенного воздействия и, в частности, от загрязнения атмосферы и почвы отработавшими газами автотранспорта.

Анализ лесоустроительньх материалов по Воронежскому учебно-опытному лесхозу за период с 1953 по 1994 год показал, что наблюдается увеличение количества поврежденных и усохших деревьев и расширение непокрытой лесом площади. Особенно большую нагрузку техногенеза испытывают сосняки, расположенные в непосредственной близости от города и автомагистрали Москва - Воронеж. Эти насаждения находятся на 4 и 5 стадиях дигрессии, и способность к самовосстановлению у них утрачена. Таких насаждений сосны насчитывается около $3 \%$ от общей площади. Около $14 \%$ территории относится к 3 стадии дигрессии и требует немедленного снижения антропогенньх нагрузок. Остальная площадь Правобережного лесничества находится преимущественно на 2 стадии дитрессии.

Учитывая вышеизложенное, можно сделать следующие выводы:

1. Наибольшая концентрация тяжельх металлов отработавших газов автомобильного транспора в снеге отмечена в пределах 24-метровой зоны, прилегающей к оси автотрассы. В лесном массиве она резко снижается и по большинству ингредиентов приближается к контролю. Исключение составил свинец, содержание которого в лесном массиве, хотя и снизилось почти вдвое, остается очень высоким и превышает контроль в 2,5 3 раза.

2. Максимальная конщентрация тяжельх металлов наблюдалась возле поста ГАИ и была следующей: железо - 6,45 - 12,21; марганец - 0,1-0,29; медь - 0,22-0,23; цинк - 0,06-0,09; свинец - 0,030,09 мг/л. Учитывая значительные превышения по этим показателям ПДК, необходимо проводить постоянный плановый контроль за состоянием здоровья работников ГАИ, обслуживающих пост на 580-м километре трассы Москва - Воро- 
неж, а также за содержанием тяжельх металлов в почве и в снежном покрове.

3. Реакция сосновьх насаждений на эмиссии выражается в снижении количества здоровьх деревьев (потери до 30\%), увеличении поврежденньх и усохших деревьев и расширении непокрытьх лесом площадей. Насаждения сосны, находящиеся в непосредственной близости от источника эмиссии, потеряли способность к самовозобновлению и относятся к участкам с 4 и 5 стадиями дигрессии и составляют примерно $3 \%$ от общей площади. Около 14\% территории относится к 3 стадии, остальная площадь Правобережного лесничества находится преимущественно на 2 стадии дигрессии.

4. Для оздоровления окружающей среды в районе автомагистралей необходимо снижать выбросы отработавших газов в атмосферу путем применения каталитических нейтрализаторов и более современньх видов топлива, а также контроля за техническим состоянием автомобилей и увеличивать объемы посадок лиственньх пород.

\section{ЛИТЕРАТУРА}

1. Федорова А. И. Биоиндексация состояния городской среды по реакциям древесных растений // Геоэкологические проблемы устойчивости развития городской среды. Воронеж: Квадрат, 1996. С. 212-213.

2. Жданова М. Дорогу охраняют деревья // Коммуна. 1995. 13 июля. № 130. С. 4.

3. Дронин Н. М. Оценка вклада непромышленньх источников тяжельх металлов в загрязнение городских почв // Геологические проблемы устойчивого развития городской среды. Воронеж: Квадрат, 1996. С. 183-184.

4. Вардуни Т. В. Перестройки хромосом в клетках высших растений как показатель мониторинга мутагенов окружающей среды: Автореф. дис. ... канд. биол. наук / Воронежский гос. ун-т. Воронеж, 1997. $24 \mathrm{c}$.

5. Иванова Ю. В. Геохимический метод и математическое моделирование при оценке загрязненности атмосферы городов // Геоэкологические проблемы устойчивого развития городской среды. Воронеж: Квадрат, 1996. С. 190-192.

6. Козлов А. Т., Васильев А. А., Зайцев А.Ф., Гашо Е. Г. Эколого-экономические проблемы региона. Воронеж: Квадрат, 1996. 168 с.
7. Пастернак П. С., Ворон В. П., Мазепа В. Г. Влияние промышленного загрязнения атмосферы на лесные экосистемы и повышение их устойчивости. М.: ЦБНТИ Гослесхоза СССР, 1985. $35 \mathrm{c}$.

8. Гриторьевская А. Я., Хриплякова В. Я., Быковская О. П. Современное состояние растительности геокомплексов г. Воронежа и ее экологоиндикационные свойства // Геоэкологические проблемы устойчивого развития городской среды. Воронеж: Квадрат, 1996. С. 223-226.

9. Пельтихина Р. И., Рубина А. М., Зурнаджи Т. Г. Оптимизация насаждений промплощадок Донбасса введением устойчивых цветочнодекоративньх интродуцентов // Там же . С. 238240.

10. Воздействие дымовых и газовых выбросов на леса в странах Западной Европы: Пер. с нем. // Лесное хозяйство за рубежом: Экспресс-информ. М.: ЦБНТТИ Гослесхоза СССР. 1985. Вып. 7. C.17-19.

11. Масштабы повреждения лесов в ФРГ // Лесное хозяйство за рубежом: Экспресс-информ. М.: ЦБНТИ Гослесхоза СССР. 1985. Вып. 19. С. 1617.

12. Десслер Х. Г. и др. Влияние загрязнений воздуха на растительность. М.: Лесная пром-сть, 1981. $184 \mathrm{c}$.

13. Гудериан Р. Загрязнение воздушной среды. М.: Мир, 1979. $200 \mathrm{c}$.

14. Луговской А. М. Биомониторинг состояния атмосферного воздуха г. Воронежа // Геоэкологические проблемы устойчивого развития городской среды. Воронеж: Квадрат, 1996. С. 240.

15. Федорова А. И., Царева Р. П., Шунелько Е. В. Устойчивость тополей к выбросам автотранспорта в условиях экосистемы г. Воронежа // Там же. C. 226-227.

16. Агафонов В. А., Бутаков Г. П., Ильдерханов А. Г. Экологическая обстановка на территории г. Казани и в Приказанском регионе // Там же. С. 186188. 
Содержание тяжелых металлов в пробах снега (среднее из трех повторностей)

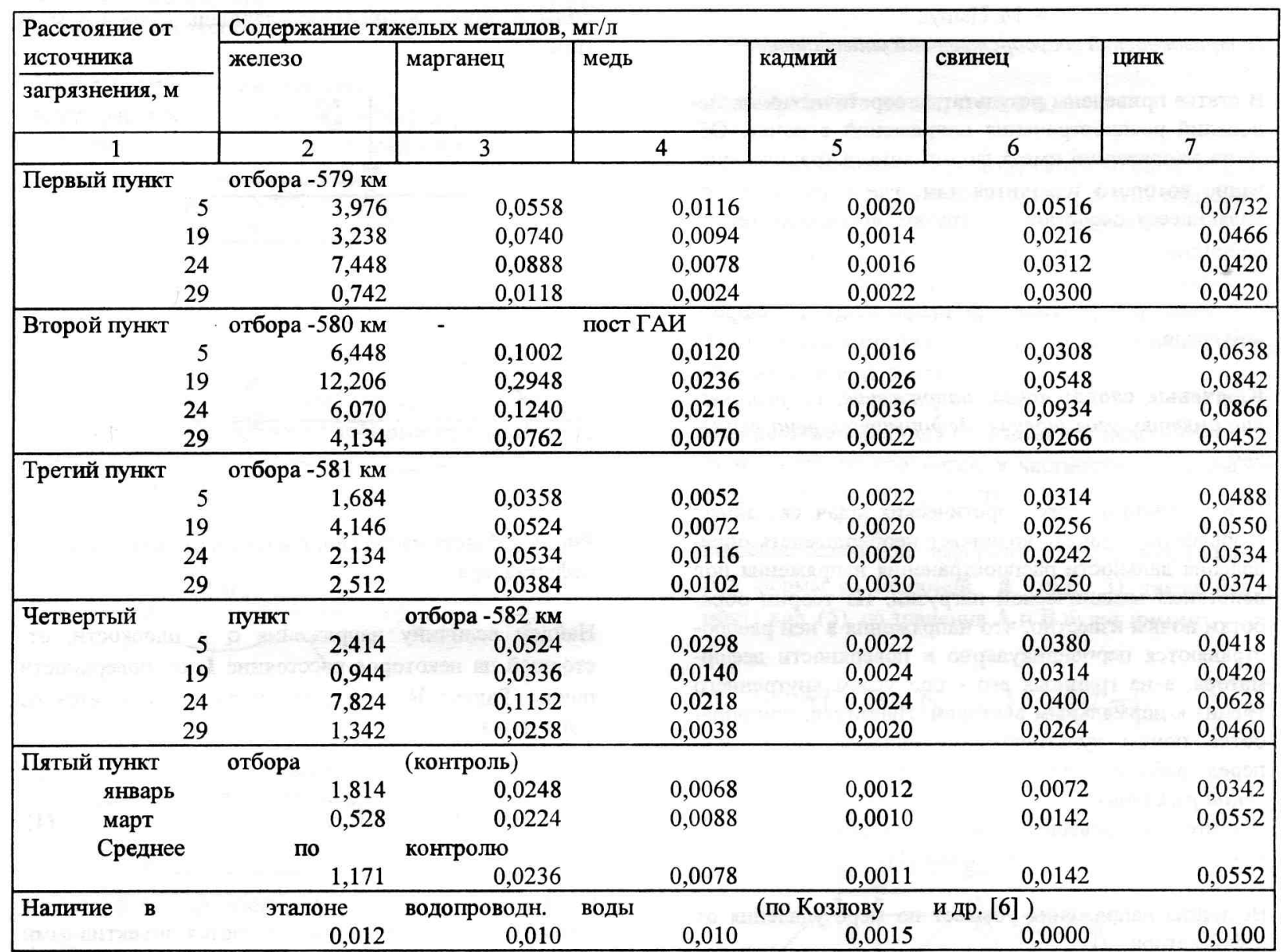

Санитарное состояние древостоя

Таблица 2

(в зависимости от удаления от источника автотранспортного воздействия)

\begin{tabular}{|c|c|c|c|c|c|c|}
\hline \multirow{2}{*}{$\begin{array}{l}\text { Расстояние } \\
\text { от шоссе, м }\end{array}$} & \multirow{2}{*}{$\begin{array}{c}\text { № кварта- } \\
\text { лов }\end{array}$} & \multirow{2}{*}{$\begin{array}{c}\text { Всего } \\
\text { деревьев, } \\
\text { шт/га }\end{array}$} & \multicolumn{4}{|c|}{ В том числе, в \% } \\
\hline & & & здоровьх & $\begin{array}{c}\text { поврежден- } \\
\text { ных }\end{array}$ & усьгхющих & yсохших \\
\hline 50 & 32 & 520 & 54 & 35 & 5 & 6 \\
\hline 100 & 32 & 1200 & 61 & 30 & 4 & 5 \\
\hline 150 & 34 & 550 & 62 & 33 & 3 & 2 \\
\hline 200 & 34 & 635 & 62 & 30 & 3 & 5 \\
\hline 400 & 36 & 550 & 69 & 21 & 4 & 6 \\
\hline
\end{tabular}

